\title{
Analisis Inflasi, Tingkat Suku Bunga, Dividend Payout Ratio, dan Current Ratio terhadap Risiko Sistematis
}

\author{
Della Ferranti \\ Fakultas Ekonomi dan Bisnis Universitas Telkom \\ Jl. Telekomunikasi Terusan Buah Batu No. 1 Bandung 40257 \\ E-Mail: dellaferranti14@gmail.com \\ Irni Yunita \\ Fakultas Ekonomi dan Bisnis Universitas Telkom \\ J1. Telekomunikasi Terusan Buah Batu No. 1 Bandung 40257 \\ E-Mail: irniyunita81@yahoo.com
}

\begin{abstract}
Investing is an activity that sacrifice the resources at this time in hopes of gaining greater profits in the future.. Before making an investment decision, an investor will consider many factors, one of which is about risk. There are two types of risk, systematic risk and unsystematic risk. Systematic risk is reflected in the value of beta coefficient. Beta indicates the volatility of stock return to market return. The purpose of this study was to determine the influence of inflation, interest rate, dividend payout ratio, and current ratio on systematic risk in State-owned Enterprises. This research was classified as descriptive verificative research. This study used data panel analysis with methods Common Effect Methods. These results indicate that inflation, interest rate, dividend payout ratio and current ratio does not have significant influence on systematic risk in State-owned Enterprises listed in Indonesia Stock Exchange period 2011-2013 either simultaneously or partially.
\end{abstract}

Keywords: inflation, interest rate, dividend payout ratio, current ratio, systematic risk.

\begin{abstract}
ABSTRAK
Investasi adalah suatu kegiatan mengorbankan sumber daya yang dimiliki saat ini dengan harapan mendapatkan keuntungan yang lebih besar di masa yang akan datang. Sebelum membuat keputusan investasi, seorang investor akan mempertimbangkan banyak faktor, salah satunya adalah risiko. Risiko ada dua tipe yaitu risiko sistematis dan risiko tidak sistematis. Risiko sistematis tercermin pada nilai koefisien beta. Beta menunjukan volatilitas return saham terhadap return pasar. Tujuan penelitian ini adalah untuk mengetahui pengaruh inflasi, tingkat suku bunga, dividend payout ratio, dan current ratio terhadap risiko sistematis pada perusahaan BUMN. Penelitian ini dikategorikan sebagai jenis penelitian deskriptif verifikatif. Penelitian ini menggunakan analisis data panel dengan metode Common Effect. Hasil penelitian ini menunjukan bahwa inflasi, tingkat suku bunga, dividend payout ratio, dan current ratio tidak berpengaruh signifikan terhadap risiko sistematis pada perusahaan BUMN yang terdaftar di Bursa Efek Indonesia periode 2011-2013 baik secara simultan maupun secara parsial.
\end{abstract}

Kata Kunci: inflasi, tingkat suku bunga, dividend payout ratio, current ratio, risiko sistematis. 


\section{PENDAHULUAN}

Investasi adalah suatu kegiatan mengorbankan sumber daya yang dimiliki saat ini dengan harapan mendapatkan keuntungan yang lebih besar di masa yang akan datang. Saham merupakan salah satu bentuk investasi yang aktif di lakukan di Indonesia. Saham adalah sertifikat yang menunjukan bukti kepemilikan suatu perusahaan (Tandelilin, 2010). Salah satu saham yang menarik minat investor adalah saham emiten BUMN.

BEI menganggap saham BUMN memiliki daya tarik tinggi di mata investor, bukan hanya investor lokal tetapi juga investor asing. (Putra, 2014).

Saham BUMN sering kali masuk dalam daftar saham Bluechip. Saham Bluechip adalah saham yang memiliki reputasi tinggi, memiliki pendapatan yang stabil, dan konsisten membayar dividen (Darmadji dan Fakhrudin, 2011). Setiap satu tahun rata-rata sebanyak 9 perusahaan masuk dalah saham Bluechips.

Selain itu, saham BUMN sering kali termasuk dalam Indeks Liquid 45 (ILQ45). Indeks LQ45 dibentuk oleh saham-saham yang paling aktif diperdagangkan (Hartono, 2013). Selama periode 2011 hingga 2013, rata-rata terdapat sekitar 11 perusahaan BUMN yang termasuk dalam Indeks LQ45.

Menurut Anggota Dewan Komisioner Otoritas Jasa Keuangan (OJK) Nurhaida, minat masyarakat dan investor terhadap saham BUMN sangat tinggi. Perusahaan plat merah tidak mudah diintervensi oleh kepentingan politik karena setiap saat diawasi langsung oleh pemegang saham minoritas yaitu publik. (jpnn.com, 2013).

Menurut Pendiri Komunitas Pemerhati Pasar Modal (KPPM) Cynthia Nadeak, saham-saham BUMN biasanya lebih aman dan fluktuasinya cenderung stabil. Selain itu, perusahaan BUMN dimiliki pemerintah sehingga kecil kemungkinannya untuk bangkrut.

Menurut Direktur Utama PT Pefindo (Pemeringkat Efek Indonesia) Khalil Rowter pada acara 'Membedah Kinerja BUMN di Pasar Modal' mengungkapkan, keunggulan BUMN di pasar modal adalah umumnya pemimpin di sektornya, memiliki tata kelola yang baik. Selain itu, dividend payout emiten BUMN lebih tinggi dibandingkan perusahaan non BUMN. (Silaban, 2010).
Menurut Menteri BUMN Mustafa Abubakar, minat investor asing untuk memiliki saham emiten BUMN terbilang sangat besar. Perusahaan BUMN mampu menguasai 26,16 persen kapitalisasi pasar atau mencapai sekitar $\mathrm{Rp} \mathrm{862,07}$ triliun dari total kapitalisasi 428 emiten yang mencapai Rp3.337,59 triliun. Meskijumlah BUMNTbkhanya 18 perusahaan atau sekitar 4 persen dari total emiten di Bursa Efek Indonesia, namun pengaruhnya sangat signifikan terhadap transaksi saham. (Putranto, 2014).

Banyak investor tidak yakin berinvestasi di perusahaan swasta, akhirnya mereka memilih berinvestasi hanya pada perusahaan BUMN. Banyak investor berasumsi bahwa perusahaan BUMN tidak akan melakukan kecurangan terhadap masyarakat pemilik saham. Selain itu, perusahaan BUMN biasanya rutin membagikan dividen dalam jumlah yang besar (Salim, 2010).

Dalam ilmu investasi terdapat asumsi bahwa investor adalah makhluk yang rasional di mana investor tidak menyukai ketidakpastian atau risiko (Tandelilin, 2010). Hampir semua investor berkarakter menjauh atau menghindar dari risiko dan mendekat pada keuntungan yang maksimal (Fahmi, 2011). Teori portofolio Markowitz menyebutkan bahwa untuk dapat menerima risiko yang lebih besar, investor harus menerima kompensasi dengan kesempatan untuk mendapatkan return yang besar pula.

Risiko dan return merupakan dua elemen yang tidak terpisahkan, risiko dan return memiliki hubungan searah dimana semakin besar risiko yang ditanggung maka semakin besar pula return yang diperoleh (Hartono, 2013).

Dalam melakukan investasi, investor akan menghadapi dua macam risiko yaitu risiko tidak sistematis dan risiko sistematis. Risiko tidak sistematis adalah risiko yang terjadi secara acak dimana tidak semua perusahaan mengalaminya. Sedangkan risiko sistematis disebut juga sebagai risiko pasar. Risiko sistematis dapat diukur dari sejauh apa suatu saham tertentu cenderung bergerak naik atau turun mengikuti pasar (Brigham dan Houston, 2010). Dampak dari risiko sistematis dirasakan oleh seluruh instrumen investasi (Widoatmodjo, 2009). Risiko sistematis tidak dapat dihindari dengan diversifikasi, risiko ini tetap ada setelah didiversifikasi karena risiko ini melekat pada pasar. Risiko sistematis muncul akibat faktorfaktor yang secara sistematis mempengaruhi sebagian 
besar perusahaan seperti perang, inflasi, resesi, dan tingkat suku bunga yang tinggi (Pangemanan, 2013).

Risiko sistematis tercermin pada nilai koefisien beta. Beta merupakan suatu pengukur volatilitas return sekuritas atau return portofolio terhadap return pasar. Beta bernilai 1 menunjukkan bahwa risiko sistematis sama dengan risiko pasar, sehingga jika return pasar naik sebesar $1 \%$, maka return sekuritas juga bergerak naik 1\% (Hartono, 2013). Menghitung beta merupakan hal penting dalam menganalisis sekuritas atau portofolio.

Dalam menganalisis saham, investor dapat melakukan analisis fundamental secara top-down untuk menilai prospek perusahaan tersebut. Hal pertama yang dilakukan adalah analisis terhadap faktorfaktor makro ekonomi yang mempengaruhi kinerja seluruh perusahaan, lalu dilanjutkan dengan analisis industri, dan akhirnya melakukan analisis perusahaan bersangkutan yang mengeluarkan sekuritas untuk menilai apakah sekuritas tersebut menguntungkan atau merugikan bagi investor (Tandelilin, 2010). Salah satu cara untuk menganalisis perusahaan adalah dengan melihat kinerja keuangannya menggunakan analisis rasio keuangan.

Kinerja pasar modal dipengaruhi oleh kondisi eksternal dan kondisi internal. Kondisi eksternal berasal dari luar perusahaan yang salah satunya adalah kondisi perekonomian suatu negara seperti inflasi dan tingkat suku bunga.

Inflasi adalah kecenderungan terjadinya peningkatan harga produk-produk secara keseluruhan (Tandelilin, 2010). Inflasi tinggi menyebabkan kinerja perusahaan menurun. Menurunnya kinerja perusahaan karena dampak inflasi akan dirasakan oleh seluruh perusahaan. Kondisi ini akan berpengaruh pada kinerja pasar modal, karena banyak perusahaan tidak dapat beroperasi secara maksimal, akibatnya pasar modal menghadapi ketidakpastian yang tinggi, dan hal ini akan berpengaruh pada harga pasar sahamsaham mereka serta indeks harga saham gabungannya (Sudiyatno dan Nuswandari, 2009).

Tingkat suku bunga merupakan harga yang bersedia untuk dibayar oleh masyarakat yang membutuhkan dana (Sudiyatno dan Nuswandari, 2009). Saat tingkat suku bunga tinggi, maka investor akan menarik investasinya pada saham dan memindahkan investasi berupa tabungan ataupun deposito (Tandelilin, 2010). Kondisi tersebut akan mengakibatkan kinerja perusahaan menurun, sehingga membuat pasar modal menjadi tidak menentu karena tidak dapat memberikan kepastian return bagi para pelaku bursa. Sehingga kinerja pasar modal akan menurun, dan menurunnya kinerja pasar modal dapat berakibat pada menurunnya harga pasar saham serta indeks harga saham gabungannya (Sudiyatno dan Nuswandari, 2009). Selain itu, kinerja pasar modal juga dipengaruhi oleh kondisi Internal. Kondisi internal berasal dari dalam perusahaan itu sendiri seperti kebijakan dividen, dan hutang.

Kebijakan dividen perusahaan harus dirumuskan dengan tujuan menyediakan pembiayaan yang memadai bagi perusahaan dan memaksimalkan kekayaan pemegang saham (Gitman, 2009). Sering kali seorang investor lebih menyukai dividen yang dibagikan daripada laba ditahan. Dividend payout ratio mengacu pada proporsi laba yang didistribusikan sebagai dividen (Subramanyam dan Wild, 2010). Dividend payout ratio tidak mempengaruhi kesejahteraan pemegang saham karena nilai perusahaan hanya ditentukan oleh kemampuan untuk menghasilkan laba dari aset yang dimiliki perusahaan (Van Horne dan Wachowicz, 2011). Namun pendapat lain menyebutkan bahwa investor lebih menyukai dividen yang tinggi karena dividen yang diterima seperti burung ditangan yang risikonya lebih kecil dibandingkan dengan dividen yang tidak dibagikan, oleh karena itu argumentasi ini disebut bird in the hand theory (Hartono, 2013).

Kegagalan dalam membayar hutang dapat menyebabkan kebangkrutan, sehingga likuiditas perusahaan harus diperhatikan. Untuk mengetahui likuiditas perusahaan salah satunya dengan memperhatikan current ratio perusahaan tersebut (Fahmi, 2011). Current ratio adalah rasio yang menunjukankemampuan perusahaan dalammemenuhi kewajiban jangka pendeknya (Gumanti, 2011). Dari sudut pandang investor, rasio ini penting untuk diamati karena kegagalan dalam membayar kewajiban dapat menyebabkan kebangkrutan perusahaan, sehingga perusahaan yang memiliki rasio likuiditas yang tinggi akan diminati para investor (Fahmi, 2011).

Inflasi, tingkat suku bunga, dividend payout ratio, dan current ratio dapat mempegaruhi risiko sistematis. Namun, penelitian yang dilakukan sebelumnya atas faktor-faktor tersebut masih menunjukan hasil yang beragam. 
Penelitian Sudiyatno \& Nuswandhari (2009) dan Pangemanan (2013) menemukan bahwa inflasi berpengaruh negatif dan signifikan terhadap risiko sistematis. Penelitian Coryaina (2013) dan Fauzi (2009) menemukan bahwa inflasi berpengaruh positif dan signifikan terhadap risiko sistematis.

Penelitian Sudiyatno \& Nuswandhari (2009) dan Pangemanan (2013) mengemukakan bahwa tingkat suku bunga berpengaruh positif dan signifikan terhadap risiko sistematis. Penelitian Julduha dan Kusumawardhani (2013) menemukan bahwa tingkat suku bunga tidak berpengaruh terhadap risiko sistematis.

Penelitian Kustini dan Pratiwi (2011) menemukan bahwa dividend payout ratio berpengaruh negatif dan signifikan terhadap risiko sistematis. Penelitian Nova et al. (2014), menemukan bahwa dividend payout ratio tidak berpengaruh terhadap risiko sistematis.

Penelitian Soeroso (2013) menemukan bahwa current ratio berpengaruh positif dan signifikan terhadap risiko sistematis. Penelitian Julduha \& Kusumawardhani (2013) dan Hutauruk et al (2014) mengemukakan bahwa current ratio tidak berpengaruh terhadap risiko sistematis.

\section{METODE}

Penelitian ini menggunakan metode kuantitatif. Metode kuantitatif adalah penelitian yang memandang gejala atau fenomena yang dapat diklasifikasikan, relatif tetap, konkrit, teramati, terukur, dan hubungan gejala bersifat sebab akibat yang digunakan untuk meneliti populasi atau sampel tertentu, dengan tujuan untuk menguji hipotesis yang telah ditetapkan (Sugiyono, 2011). Penelitian ini merupakan jenis penelitian deskriptif verifikatif. Penelitian deskriptif adalah penelitian yang dimaksudkan untuk menyelidiki keadaan, kondisi, situasi, peristiwa, kegiatan, dan lainlain. Sedangkan penelitian verifikatif adalah penelitian untuk menguji kebenaran dari suatu hipotesis melalui pengumpulan data di lapangan (Arikunto, 2010).
Populasi pada penelitian ini adalah seluruh perusahaan BUMN yang terdaftar di Bursa Efek Indonesia yaitu sebanyak 20 perusahaan. Teknik sampling yang digunakan pada penelitian ini adalah purposive sampling. Purposive sampling adalah teknik penentuan sampel dengan kriteria tertentu (Sugiyono, 2011). Tabel 1. adalah kriteria sampel pada penelitian ini.

Pada penelitian ini terdapat empat variabel independen yang terdiri dari Inflasi $\left(\mathrm{X}_{1}\right)$, Tingkat Suku Bunga $\left(\mathrm{X}_{2}\right)$, Dividend payout ratio $\left(\mathrm{X}_{3}\right)$, dan Current ratio $\left(\mathrm{X}_{4}\right)$, dan satu variabel independen, yaitu risiko sistematis yang tercermin dalam nilai koefisien beta $(\beta)$ dapat dilihat pada Tabel 2.

Data yang digunakan pada penelitian ini adalah data sekunder. Data sekunder adalah data yang diperoleh melalui sumber yang sudah ada sehingga tidak perlu dikumpulkan sendiri oleh peneliti (Sekaran, 2011). Metode pengumpulan data pada penelitian ini ialah metode dokumentasi. Metode dokumentasi adalah mencari data mengenai hal-hal atau variabel yang berupa catatan, transkrip, buku, surat kabar, majalah, prasasti, notulen rapat, dan sebagainya (Arikunto, 2010).

Penelitian inimenggunakan analisis deskriptifdan analisis regresi data panel. Tujuan analisis deskriptif adalah untuk memberikan gambaran aspek-aspek yang relevan dengan fenomena dari perspektif seseorang, organisasi, atau lainnya. Pada analisis deskriptif, data dikumpulkan kemudian diolah dengan rumus-rumus statistika yang sudah ada ataupun menggunakan tools komputer (Arikunto, 2010).

Analisis regresi digunakanuntuk memprediksikan seberapa jauh perubahan nilai variabel dependen, bila nilai variabel independen dimanipulasi (dinaikan atau diturunkan) (Sugiyono, 2010). Data panel merupakan penggabungan data time series dengan cross section. Sehingga metode analisis regresi menggunakan data panel disebut regresi data panel (Juanda dan Junaidi, 2012).

Tabel 1. Populasi dan Sampel Penelitian

\begin{tabular}{lc}
\hline \multicolumn{1}{c}{ Keterangan } & Jumlah Perusahaan \\
\hline Populasi perusahaan BUMN yang terdaftar di Bursa Efek Indonesia & 20 \\
Perusahaan yang tidak masuk sampel penelitian: & 3 \\
a. Tidak terdaftar di Bursa Efek Indonesia dari awal Tahun 2011 hingga akhir Tahun 2013 & 6 \\
b. Tidak memiliki laporan keuangan yang telah teraudit dan tidak memiliki kelengkapan data & 11 \\
$\quad$ variabel yang dibutuhkan Tahun 2011-2013 & 1
\end{tabular}


Tabel 2. Variabel Operasional

\begin{tabular}{|c|c|c|c|c|}
\hline No & Variabel & Definisi & Rumus & Skala \\
\hline 1. & Inflasi $\left(X_{1}\right)$ & $\begin{array}{l}\text { Inflasi adalah kecenderungan terjadinya peningkatan } \\
\text { harga produk-produk secara keseluruhan (Tandelilin, } \\
\text { 2010). }\end{array}$ & $I R_{x}=\frac{C P I_{x}-C P I_{x-1}}{C P I_{x-1}} \times 100 \%$ & Rasio \\
\hline 2. & $\begin{array}{l}\text { Tingkat suku } \\
\text { bunga }\left(\mathrm{X}_{2}\right)\end{array}$ & $\begin{array}{l}\text { Tingkat suku bunga adalah biaya yang dibayarkan } \\
\text { oleh peminjam dana (Gitman, 2009). }\end{array}$ & (Sumber: bi.go.id) & Rasio \\
\hline 3. & $\begin{array}{l}\text { Dividend } \\
\text { payout ratio } \\
(\mathrm{DPR})\left(\mathrm{X}_{3}\right)\end{array}$ & $\begin{array}{l}\text { Dividend payout ratio adalah persentase setiap dolar } \\
\text { yang diperoleh perusahaan yang didistribusikan } \\
\text { kepada pemilik dalam bentuk uang tunai (Gitman, } \\
\text { 2009). }\end{array}$ & $D P R=\frac{\text { Dividen Tahunan }}{\text { Pendapatan Tahunan }}$ & Rasio \\
\hline 4. & $\begin{array}{l}\text { Current ratio } \\
(\mathrm{CR})\left(\mathrm{X}_{4}\right)\end{array}$ & $\begin{array}{l}\text { Current ratio adalah kemampuan perusahaan untuk } \\
\text { membayar kewajiban jangka pendeknya dengan } \\
\text { menggunakan aktiva lancarnya (Van Horne \& } \\
\text { Wachowicz, 2012). }\end{array}$ & $C R=\frac{\text { Aktiva Lancar }}{\text { Hutang Lancar }}$ & Rasio \\
\hline 5. & $\begin{array}{l}\text { Risiko } \\
\text { sistematis } \\
\text { (Y) }\end{array}$ & $\begin{array}{l}\text { Risiko sistematis adalah variabilitas return saham } \\
\text { atau portofolio yang disebabkan oleh perubahan } \\
\text { dalam return pasar secara keseluruhan (Van Horne \& } \\
\text { Wachowicz, 2012). }\end{array}$ & $\beta=\frac{\sum R_{i} R_{m}-n \bar{R}_{i} \bar{R}_{m}}{\sum R_{m}{ }^{2}-n \bar{R}_{m}^{2}}$ & Rasio \\
\hline
\end{tabular}

Analisis regresi data panel terdiri dari 3 metode yaitu, Common Effect, Fixed Effect dan Random Effect. Untuk memilih metode yang tepat maka dapat melakukan uji Chow dan Uji Hausman.

\section{HASIL}

\section{Analisis Deskriptif}

Pada penelitian ini, analisis deskriptif menggunakan pengolah data SPSS. Inflasi terendah adalah 0,037. Sedangkan inflasi tertinggi adalah sebesar 0,081. Mean (rata-rata) inflasi yang terjadi dari Tahun 2011 hingga Tahun 2013 adalah sebesar 0,0533 . Hal ini berarti bahwa rata-rata kenaikan harga yang terjadi dari Tahun 2011 hingga Tahun 2013 adalah sebesar 5,3\%.

Tingkat suku bunga terendah adalah sebesar 0,060 Sedangkan tingkat suku bunga tertinggi adalah sebesar 0,07. Mean (rata-rata) tingkat suku bunga yang terjadi dari Tahun 2011 hingga Tahun 2013 adalah sebesar 0,0633. Dengan tingkat suku bunga sebesar $6,3 \%$ berarti bahwa biaya yang harus dibayar oleh seseorang untuk meminjam dana adalah $6,3 \%$ dari dana yang ia pinjam atau pendapatan yang diperoleh para pemilik dana adalah sebesar $6,3 \%$ dari dana yang ia pinjamkan.

Dividend payout ratio terendah adalah sebesar 0,1 . Sedangkan dividend payout ratio tertinggi adalah sebesar 0,700. Mean (rata-rata) dividend payout ratio perusahaan BUMN sepanjang Tahun 2011 hingga Tahun 2013 adalah sebesar 0,40615. Dengan dividend payout ratio sebesar $40,6 \%$ berarti besarnya dividen yang dibagikan kepada pemegang saham adalah $40,6 \%$ dari laba bersih yang diperoleh perusahaan.

Current ratio tertinggi adalah sebesar 10,642. Sedangkan current ratio terendah adalah sebesar 0,682. Mean (rata-rata) current ratio perusahaan BUMN sepanjang Tahun 2011 hingga Tahun 2013 adalah sebesar 2,41655. Dengan current ratio sebesar 2,41655 berarti kemampuan perusahaan dalam memenuhi hutang jangka pendeknya adalah sebesar 2,41655 kali dari hutangnya.

Risiko sistematis terendah adalah sebesar $-0,600$. Risiko sistematis tertinggi adalah sebesar 3,405 . Sedangkan mean (rata-rata) risiko sistematis perusahaan BUMN sepanjang Tahun 2011 hingga Tahun 2013 adalah sebesar 1,4322. Dengan risiko sistematis sebesar 1,4322 berarti ketika return pasar naik sebesar 1 maka return saham juga akan naik sebesar 1,4322. Standar deviasi risiko sistematis dari Tahun 2011 hingga Tahun 2013 adalah sebesar 1,039274. Standar deviasi menunjukan ukuran penyebaran data dari rata-rata.

\section{Analisis Regresi Data Panel}

Pada penelitian ini, analisis regresi data panel menggunakan pengolah data Eviews. Tabel 3 adalah hasil Uji Chow pada penelitian ini. 
Tabel 3. Hasil Uji Chow

Redundant Fixed Effects Tests

Pool:TA

Test cross-section fixed effetcs

\begin{tabular}{lrrr}
\hline \multicolumn{1}{c}{ Effect Test } & Statistic & \multicolumn{1}{c}{ d.f } & \multicolumn{1}{c}{ Prob. } \\
\hline Cross-section F & 0.827661 & $(10.18)$ & 0.6088 \\
Cross-section Chi-square & 12.484145 & 10 & 0.2540 \\
\hline
\end{tabular}

Sumber: data diolah

Berdasarkan Tabel 3., maka diperoleh nilai p-value cross section Chi-Square sebesar 0,2540 dan p-value cross section $\mathrm{F}$ sebesar 0,6088 , karena nilai p-value cross section Chi-Square $\geq 0,05$ atau nilai p-value cross section $\mathrm{F} \geq 0,05$ maka $\mathrm{H}_{0}$ diterima, maka model yang tepat untuk penelitian ini adalah Common Effect.

Dengan diketahuinya model data panel yang tepat yaitu Common Effect, maka uji Hausman tidak perlu dilakukan. Berikut Tabel 4. menyajikan hasil regresi data panel menggunakan metode Common Effect.

Tabel 4. Hasil Analisis Regresi Metode Common Effect

\begin{tabular}{crrrr}
\hline Variable & Coefficient & Std. Error & t-Static & \multicolumn{1}{c}{ Prob. } \\
\hline C & 1.691323 & 3.219275 & 0.525374 & 0.6035 \\
INFLASI? & 4.020182 & 10.20454 & 0.393960 & 0.6966 \\
TINGSB? & 4.722825 & 53.79806 & 0.087788 & 0.9307 \\
DPR? & -2.306134 & 1.263688 & -1.824924 & 0.0787 \\
\multicolumn{1}{c}{ CR? } & 0.068595 & 0.101966 & 0.672722 & 0.5066 \\
\hline R-squared & 0.110420 & Mean dependet var & 1.432208 \\
$\begin{array}{l}\text { Adjusted } \\
\text { R-squared }\end{array}$ & -0.016663 & S.D. dependent var & 1.039281 \\
$\begin{array}{l}\text { S.E. of } \\
\text { regression }\end{array}$ & 1.047904 & Akaike info criterion & 3.070189 \\
$\begin{array}{l}\text { Sum squared } \\
\text { resid }\end{array}$ & 30.74690 & Schwarz criterion & 3.296932 \\
$\begin{array}{l}\text { Log } \\
\text { likelihood }\end{array}$ & -45.65812 & Hannan-Quinn criter. & 3.146481 \\
\begin{tabular}{l} 
F-statistic \\
\hline
\end{tabular} & 0.868881 & Durbin-Watson stat & 2.068543 \\
\hline
\end{tabular}

Sumber: data diolah

Berdasarkan Tabel 4., maka dapat diketahui model persamaan regresi data panel sebagai berikut. RISIKO SISTEMATIS $=$ $1,691323+4,020182$ INFLASI + 4,722825TING.SB $-2,306134 \mathrm{DPR}+0,068595 \mathrm{CR}$
Persamaan tersebut dapat diartikan sebagai berikut: 1) Nilai konstan sebesar 1,691323, artinya jika variabel inflasi, tingkat suku bunga, dividend payout ratio, dan current ratio bernilai nol maka risiko sistematis perusahaan BUMN adalah sebesar 1,691323 ; 2) Koefisien Inflasi $\left(\mathrm{X}_{1}\right)$ adalah sebesar 4,020182, artinya jika terjadi peningkatan tingkat inflasi sebesar 1 (dengan asumsi variabel konstan) maka risiko sistematis akan mengalami peningkatan sebesar 4,020182; 3) Koefisien Tingkat Suku Bunga $\left(\mathrm{X}_{2}\right)$ adalah sebesar 4,722825 , artinya jika terjadi peningkatan tingkat suku bunga sebesar 1 (dengan asumsi variabel konstan) maka risiko sistematis akan mengalami peningkatan sebesar 4,722825; 4) Koefisien Dividend payout ratio $\left(\mathrm{X}_{3}\right)$ adalah sebesar $-2,306134$, artinya jika terjadi peningkatan dividend payout ratio sebesar 1 (dengan asumsi variabel konstan) maka risiko sistematis akan mengalami penurunan sebesar 2,306134; dan 5) Koefisien Current ratio $\left(\mathrm{X}_{4}\right)$ adalah sebesar 0,068595 , artinya jika terjadi peningkatan tingkat current ratio sebesar 1 (dengan asumsi variabel konstan) maka risiko sistematis akan mengalami peningkatan sebesar 0,068595 .

\section{Uji Koefisien Determinasi $\left(\mathbf{R}^{2}\right)$}

Berdasarkan Tabel 4. maka diketahui bahwa nilai koefisien determinasi adalah sebesar 0,110420 atau $11 \%$ yang artinya variabel inflasi, tingkat suku bunga, dividend payout ratio, dan current ratio mampu menerangkan risiko sistematis sebesar $11 \%$ sedangkan sisanya $89 \%$ dijelaskan oleh variabel lain diluar penelitian.

\section{Uji Hipotesis}

Penelitian ini menggunakan tingkat signifikansi $(\alpha)$ sebesar 5\%. Berdasarkan Tabel 4 maka diketahui bahwa $\mathrm{F}_{\text {tabel }}>\mathrm{F}_{\text {statistik }}$ yaitu $2,71>0,868881$, maka $\mathrm{H}_{\mathrm{o}}$ diterima yang artinya tidak terdapat pengaruh signifikan antara inflasi, tingkat suku bunga, dividend payout ratio, dan current ratio terhadap risiko sistematis secara simultan pada perusahaan BUMN yang terdaftar di Bursa Efek Indonesia Tahun 20112013.

Dalam penelitian ini, nilai $t_{\text {tabel }}$ adalah sebesar $1,70113(\mathrm{n}-\mathrm{k}=33-5=28)$. Oleh karena itu, hasil uji parsial adalah sebagai berikut: 1) Variabel Inflasi $\left(\mathrm{X}_{1}\right)$, berdasarkan Tabel 4 memiliki nilai $\mathrm{t}_{\text {tabel }}>\mathrm{t}_{\text {statistik }}$ yaitu $1,70113>0,393960$ maka $\mathrm{H}_{0}$ diterima yang artinya tidak terdapat pengaruh signifikan antara 
inflasi terhadap risiko sistematis pada perusahaan BUMN yang terdaftar di Bursa Efek Indonesia Tahun 2011-2013; 2) Variabel Tingkat Suku Bunga $\left(\mathrm{X}_{2}\right)$, berdasarkan Tabel 4. memiliki nilai $\mathrm{t}_{\text {tabel }}>\mathrm{t}_{\text {statistik }}$ yaitu $1,70113>0,087788$ maka $\mathrm{H}_{0}$ diterima yang artinya tidak terdapat pengaruh signifikan antara tingkat suku bunga terhadap risiko sistematis pada perusahaan BUMN yang terdaftar di Bursa Efek Indonesia Tahun 2011-2013; 3) Variabel Dividend payout ratio $\left(\mathrm{X}_{3}\right)$, berdasarkan Tabel 4. memiliki nilai $\mathrm{t}_{\text {tabel }}>\mathrm{t}_{\text {statistik }}$ yaitu $1,70113>-1,824924$ maka $\mathrm{H}_{0}$ diterima yang artinya tidak terdapat pengaruh signifikan antara dividend payout ratio terhadap risiko sistematis pada perusahaan BUMN yang terdaftar di Bursa Efek Indonesia Tahun 2011-2013; dan 5) Variabel Current ratio $\left(\mathrm{X}_{4}\right)$, berdasarkan Tabel 4. memiliki nilai $\mathrm{t}_{\text {tabel }}$ $>\mathrm{t}_{\text {statistik }}$ yaitu 1,70113 $>0,672722$ maka $\mathrm{H}_{0}$ diterima yang artinya tidak terdapat pengaruh signifikan antara current ratio terhadap risiko sistematis pada perusahaan BUMN yang terdaftar di Bursa Efek Indonesia Tahun 2011-2013.

\section{PEMBAHASAN}

\section{Pengaruh Inflasi terhadap Risiko Sistematis}

Berdasarkan hasil pengujian regresi data panel model Common Effect, inflasi memiliki nilai $t_{\text {tabel }}>$ $\mathrm{t}_{\text {statistik }}$ maka hipotesis awal pada penelitian ini ditolak. Hasil penelitian ini sesuai dengan hasil penelitian yang dilakukan oleh Andayani et al. (2010) yang menyatakan bahwa tidak terdapat pengaruh signifikan antara inflasi terhadap risiko sistematis. Namun, hasil penelitian ini berbeda dengan hasil penelitian yang dilakukan oleh Sudiyatno \& Nuswhandari (2009), Pangemanan (2013), Suparno (2010), dan Fauzi (2009) yang menyatakan bahwa terdapat pengaruh signifikan antara inflasi terhadap risiko sistematis.

Ditolaknya hipotesis awal disebabkan karena investor lebih banyak mempertimbangkan variabelvariabel lainnya dalam melakukan keputusan investasi. Bahkan untuk investasi pada saham-saham LQ45, investor cenderung tidak terpengaruh kondisi makroekonomi yang ada, sehingga kapitalisasi pasar saham-saham ini tetap tinggi (Andayani et al., 2010). Selain itu, dikarenakan inflasi Indonesia Tahun 2011 hingga 2013 masih dalam posisi stabil maka investor masih bisa menerima. Namun, jika inflasi menembus angka 10 persen, pasar modal akan terganggu (Kewal, 2012). Sehingga inflasi tidak mempengaruhi perubahan harga saham dan perubahan return sehingga tidak berpengaruh terhadap risiko sistematis perusahaan BUMN.

\section{Pengaruh Tingkat Suku Bunga terhadap Risiko Sistematis}

Berdasarkan hasil pengujian regresi data panel model Common Effect, tingkat suku bunga memiliki nilai $t_{\text {tabel }}>t_{\text {statistik }}$ maka hipotesis awal pada penelitian ini ditolak. Hasil penelitian ini sesuai dengan hasil penelitian yang dilakukan oleh Julduha \& Kusumawardhani (2013) dan Andayani et al (2010) yang menyatakan bahwa tidak terdapat pengaruh signifikan antara tingkat suku bunga terhadap risiko sistematis. Namun, hasil penelitian ini berbeda dengan hasil penelitian yang dilakukan oleh Sudiyatno \& Nuswhandari (2009), Makaryanawati \& Ulum (2009), Pangemanan (2013), dan Ni'mah (2013) yang menyatakan bahwa terdapat pengaruh signifikan antara tingkat suku bunga terhadap risiko sistematis.

Ditolaknya hipotesis awal disebabkan karena perusahaan BUMN memiliki pendapatan yang stabil, hal ini tercermin dengan masuknya perusahaan BUMN pada saham Bluechip dan Indeks LQ45, sehingga tingkat suku bunga tidak mempengaruhi keputusan investor dalam berinvestasi. Sehingga menyebabkan tingkat suku bunga tidak mempengaruhi perubahan harga saham dan perubahan return sehingga tidak berpengaruh terhadap risiko sistematis perusahaan BUMN.

\section{Pengaruh Dividend payout ratio terhadap Risiko Sistematis}

Berdasarkan hasil pengujian regresi data panel model Common Effect, tingkat suku bunga memiliki nilai $t_{\text {tabel }}>t_{\text {statistik }}$ maka hipotesis awal pada penelitian ini ditolak. Hasil penelitian ini sesuai dengan hasil penelitian yang dilakukan oleh Nova et al. (2014) yang menyatakan bahwa tidak terdapat pengaruh signifikan antara dividend payout ratio terhadap risiko sistematis. Namun, hasil penelitian ini berbeda dengan hasil penelitian yang dilakukan oleh Kustini dan Pratiwi (2011) yang menyatakan bahwa terdapat pengaruh signifikan antara dividend payout ratio terhadap risiko sistematis.

Dengan ditolaknya hipotesis awal mengindikasikan bahwa dalam membuat keputusan investasi, seorang investor tidak terlalu 
memperhatikan dividend payout ratio karena tidak mempengaruhi kesejahteraannya. Dividend payout ratio tidak mempengaruhi kesejahteraan pemegang saham karena nilai perusahaan hanya ditentukan oleh kemampuan untuk menghasilkan laba dari aset yang dimiliki perusahaan (Van Horne dan Wachowicz, 2011). Oleh karena itu, dividend payout ratio tidak mempengaruhi perubahan harga saham dan perubahan return sehingga tidak berpengaruh terhadap risiko sistematis perusahaan BUMN.

\section{Pengaruh Current ratio terhadap Risiko Sistematis}

Berdasarkan hasil pengujian regresi data panel model Common Effect, tingkat suku bunga memiliki nilai $\mathrm{t}_{\text {tabel }}>\mathrm{t}_{\text {statistik }}$ maka hipotesis awal pada penelitian ini ditolak. Hasil penelitian ini sesuai dengan hasil penelitian yang dilakukan oleh Makaryanawati \& Ulum (2009), Julduha \& Kusumawardhani (2013), Andayani et al. (2010), Masrendra et al. (2010), Hutauruk et al. (2014), Ni'mah (2013), dan Anto (2012) yang menyatakan bahwa tidak terdapat pengaruh signifikan antara current ratio terhadap risiko sistematis. Namun, hasil penelitian ini berbeda dengan hasil penelitian yang dilakukan oleh Nova et al. (2014), Soeroso (2013), dan Suparno (2010), yang menyatakan bahwa terdapat pengaruh signifikan antara current ratio terhadap risiko sistematis.

Perusahaan BUMN pada umumnya adalah perusahaan yang mapan dan pemimpin di sektornya, sehingga untuk membuat keputusan investasi, seorang investor tidak terlalu memperhatikan kemampuan perusahaan dalam memenuhi hutang jangka pendeknya. Oleh karena itu, current ratio tidak mempengaruhi perubahan harga saham dan perubahan return sehingga tidak berpengaruh terhadap risiko sistematis perushaan BUMN.

\section{KESIMPULAN}

Perkembangan inflasi dan risiko sistematis cenderung meningkat, sedangkan tingkat suku bunga, dividend payout ratio, dan current ratio cenderung menurun. Inflasi, tingkat suku bunga, dividend payout ratio, dan current ratio secara parsial tidak berpengaruh signifikan terhadap risiko sistematis pada perusahaan BUMN yang terdaftar di Bursa Efek Indonesia Tahun 2011-2013. Inflasi, tingkat suku bunga, dividend payout ratio, dan current ratio secara simultan tidak berpengaruh signifikan terhadap risiko sistematis pada perusahaan BUMN yang terdaftar di Bursa Efek Indonesia Tahun 2011-2013.

Bagi investor yang ingin melakukan investasi pada saham BUMN, faktor eksternal seperti inflasi dan tingkat suku bunga serta faktor internal seperti dividend payout ratio, dan current ratio tidak dapat dijadikan acuan utama untuk membuat keputusan investasi. Investor dapat berinvestasi pada saham BUMN karena sahamnya memiliki pergerakan yang stabil sehingga jika mengalami penurunan maka penurunan tersebut tidak sebesar penurunan pada saham-saham non BUMN sehingga tingkat risikonya lebih kecil dari saham non BUMN.

Pada penelitian ini terdapat hasil temuan yang tidak sesuai dengan teori yang sudah ada. Oleh karena itu, peneliti selanjutnya diharapkan dapat menambah variabel lain yang diduga mempengaruhi risiko sistematis, serta menggunakan objek penelitian yang lebih banyak dengan periode waktu yang lebih panjang agar hasilnya dapat menggambarkan kondisi pasar modal Indonesia yang sebenarnya.

\section{DAFTAR PUSTAKA}

\section{Saham BUMN Diminati Investor.}

http://www.jpnn.com/read/2013/02/22/159600/

Saham-BUMN-Diminati-Investor (diakses tanggal

7 Oktober 2014).

Andayani, Dwi, Nining Setyowati, Moeljadi P. S. \& M. Harry Susanto. 2010. Pengaruh Variabel Internal dan Eksternal Perusahaan terhadap Risiko Sistematis Saham pada Kondisi yang Berbeda. Jurnal Wacana, 13(2): 244-259.

Anto, Ines Ham. 2012. Analisis Faktor Fundamental Keuangan terhadap Risiko Sistematis pada Perusahaan ILQ45. Skripsi Universitas Hasanudin Makassar: diterbitkan.

Arikunto, Suharsimi. 2010. Prosedur Penelitian: Suatu Pendekatan Praktik. Jakarta: Rineka Cipta.

Brigham, Eugene F. \& Joel F. Houston. 2010. DasarDasar Manajemen Keuangan (edisi ke-11). Jakarta: Salemba Empat.

Coryaina, Vina Rahmantika. 2013. Pengaruh Faktor Fundamental Perusahaan dan Ekonomi Makro terhadap Risiko Investasi (Beta) Saham Syariah. Skripsi Universitas Islam Negri Sunan Kalijaga Yogyakarta: diterbitkan. 
Darmadji, Tjiptono \& Hendy M. Fakhrudin. 2011. Pasar Modal Indonesia (edisi ke-3). Jakarta: Salemba Empat.

Fahmi, Irham. 2011. Analisis Laporan Keuangan. Jakarta: Salemba Empat.

Fauzi, Ahmad. 2009. Analisis Pengaruh Indikator Fundamental dan Makro Ekonomi terhadap Beta Saham. Skripsi Universitas Islam Negri Syarif Hidayatullah Jakarta: diterbitkan.

Gitman, Lawrence J. 2009. Principles of Managerial Finance $\left(12^{\text {nd }}\right.$ edition). Boston: Pearson International Edition.

Gumanti, Tatang Ary. 2011. Manajemen Investasi. Jakarta: Mitra Wacana Media.

Hartono, Jogiyanto. 2013. Teori Portofolio dan Analisis Investasi (edisi ke-8). Yogyakarta: BPFE.

Hutauruk, Martinus Robert, Sri Mintarti \& Ardi Paminto. 2014. Influence of Fundamental Ratio, Market Ratio and Business Performance to The Systematic Risk and Their Impacts to The Return on Shares at The Agricultural Sector Companies at The Indonesia Stock Exchange for The Period of 2010-2013. Academic Reearch International, 5(5): 149-168.

Juanda, Bambang \& Junaidi. 2012. Ekonometrika Deret Waktu. Bogor: IPB Press.

Julduha, Nucifera \& Indra Kusumawardhani. 2013. Pengaruh Net Profit Margin, Current ratio, Debt to Assets, dan Tingkat Suku Bunga terhadap Beta Saham Syariah. Jurnal Buletin Studi Ekonomi, 18(2): 144-152.

Kewal, Suramaya Suci. 2012. Pengaruh Inflasi, Suku Bunga, Kurs, dan Pertumbuhan PDB terhadap Indeks Harga Saham Gabungan. Jurnal Economica, 8(1): 53-64.

Kustini, Sri \& Selvi Pratiwi. 2011. Pengaruh Dividend payout ratio, Return on Assets, dan Earning Variability terhadap Beta Saham Syariah. Jurnal Dinamika Akuntansi, 3(2): 139-148.

Makaryanawati \& Misbachul Ulum. 2009. Pengaruh Tingkat Suku Bunga dan Tingkat Likuiditas Perusahaan terhadap Risiko Investasi Saham yang Terdaftar pada Jakarta Islamic Index. Jurnal Ekonomi Bisnis, 14(1): 49-60.

Masrendra, Christian Hery, Kristyana Dananti \& Magdalena Nany. 2010. Analisis Pengaruh Financial Leverage, Liquidity, Assets Growth, dan Asset Size terhadap Beta Saham. Jurnal Perspektif Ekonomi, 3(2): 121-127.
Ni'mah, Nailatun. 2013. Analisis Pengaruh Tingkat Suku Bunga, Tingkat Likuiditas, Profitabilitas, dan Leverage Perusahaan terhadap Risiko Investasi. Skripsi Universitas Islam Negri Sunan Kalijaga Yogyakarta: diterbitkan.

Nova, I. Kadek Satria, I Wayan Ramantha \& Made Gede Wirakusuma. 2014. Analisis Variabel Keuangan sebagai Prediktor Beta Saham. Jurnal Ekonomi dan Bisnis Universitas Udayana, 56-67.

Pangemanan, Vanessa. 2013. Inflasi, Nilai Tukar, dan Suku Bunga terhadap Risiko Sistematis. Jurnal EMBA, 1(3): 189-196.

Putranto, E. Dwi. Laba 18 BUMN Capai Rp 43 T. www.republika.co.id (diakses tanggal 23 Oktober 2014).

Putra, Dwitya. BEI Dukung Investor Lokal Banyak Serap Saham BUMN. www.infobanksnews.com (diakses tanggal 7 Oktober 2014).

Salim, Joko. 2010. 108 Tanya Jawab Tentang Investasi. Jakarta: Visimedia.

Sekaran, Uma. 2011. Metodologi Penelitian untuk Bisnis (edisi ke-4). Jakarta: Salemba Empat.

Silaban, Susan. 2010. Pefindo: Emiten BUMN Gairahkan Investor. http://pasarmodal.inilah. $\mathrm{com} / \mathrm{read} /$ detail/478161/pefindo-emiten-bumngairahkan-investor-asing (diakses tanggal 23 Oktober 2014).

Soeroso, Anditya. 2013. Faktor Fundamental (Current ratio, Total Debt to Equity Ratio, Total Asset Turnover, Return on Investment) terhadap Risiko Sistematis Pada Industri Food and Beverages di Bursa Efek Indonesia. Jurnal EMBA, 1(4): 16871689.

Subramanyam, K. R. \& John J. Wild. 2010. Analisis Laporan Keuangan. (edisi ke-10). Jakarta: Salemba Empat.

Sudiyatno, Bambang \& Cahyani Nuswandhari. 2009. Peranan Beberapa Indikator Ekonomi Dalam Mempengaruhi Risiko Sistematis Jurnal Dinamika Keuangan dan Perbankan, 1(2): 66-81.

Sugiyono. 2010. Statistika untuk Penelitian. Bandung: Alfabeta.

Sugiyono. 2011. Metode Penelitian Kuantitatif, Kualitatif, dan Kombinasi (Mixed Methods). Bandung: Alfabeta.

Suparno. 2010. Tingkat Inflasi dan Rasio Likuiditas terhadap Risiko Saham Syariah yang terdaftar di Jakarta Islamic Index. Jurnal Telaah \& Riset Akuntansi, 3(1): 1-9. 
Tandelilin, Edarus. 2010. Teori Portofolio dan Investasi: Teori dan Aplikasi (edisi Pertama). Yogyakarta: Kanisius.

Van Horne, James C. \& John M. Wachowicz. 2011. Prinsip-Prinsip Manajemen Keuangan. Jakarta: Salemba Empat.
Widoatmodjo, Sawidji. 2009. Pasar Modal Indonesia: Pengantar \& Studi Kasus. Bogor: Ghalia Indonesia. 